\title{
Comparison of the Dissolution Behavior in Ethanol with the Dissolution Behavior in Water for Tris(amino acidato)cobalt(III)
}

\author{
Yasuki Yoshimura \\ Environmental Sciences, Faculty of Humanities and Social Sciences, Iwate University, Ueda, Morioka 020-8550
}

Received March 24, 2004; E-mail: yasumura@iwate-u.ac.jp

\begin{abstract}
The free energy $\left(\Delta_{\text {dis }} G^{\circ}\right)$, enthalpy $\left(\Delta_{\text {dis }} H^{\circ}\right)$, and entropy of dissolution $\left(\Delta_{\text {dis }} S^{\circ}\right)$ for tris(amino acidato $)$ cobalt(III) were estimated from the temperature dependence of the solubilities in water, aqueous $\mathrm{Bu}_{4} \mathrm{NBr}$ solutions, and ethanol. For $m e r$-tris $\left(\beta\right.$-alaninato)cobalt(III) $\left(\right.$ mer- $\left.\left[\mathrm{Co}(\beta \text {-ala })_{3}\right]\right)$, mer- $(+)$-tris(L-threoninato)cobalt(III) $\left(\right.$ mer- $\left.(+)-\left[\mathrm{Co}(\mathrm{L}-\mathrm{thr})_{3}\right]\right)$, and $f a c-(-)$-tris(L-prolinato)cobalt(III) (fac-(-)-[Co(L-pro $\left.\left.)_{3}\right]\right), \Delta_{\mathrm{tr}} H^{\circ}$ and $\Delta_{\mathrm{tr}} S^{\circ}$ of the transfer process from water to $\mathrm{Bu}_{4} \mathrm{NBr}$ solutions indicate that these chelates have rather a hydrophilic character. In addition to these chelates, for mer-(-)-tris(L-alaninato)cobalt(III) (mer-(-)-[Co(L-ala) 3$]$ ), mer-(-)- and fac-(-)-tris(L-valinato)cobalt(III) (mer-(-)and fac- $^{-}-$- $\left.\left[\mathrm{Co}(\mathrm{L}-\mathrm{val})_{3}\right]\right)$, mer-(+)-tris(L-leucinato)cobalt(III) (mer-(+)-[Co(L-leu $\left.\left.)_{3}\right]\right)$, and so on, the dissolution behavior in ethanol was compared with that in water by using $\Delta_{\text {dis }} G^{\circ}, \Delta_{\text {dis }} H^{\circ}$, and $\Delta_{\text {dis }} S^{\circ}$ in both solvents. The dissolution behavior of these chelates may be divided into two groups, that is, a group composed of hydrophilic chelates and another group composed of hydrophobic chelates. In the former, the solubilities in water are larger than those in ethanol owing to both smaller $\Delta_{\text {dis }} H^{\circ}$ and larger $\Delta_{\text {dis }} S^{\circ}$ in water. In the latter, the solubilities in ethanol are larger than those in water owing to larger $\Delta_{\text {dis }} S^{\circ}$ in ethanol.
\end{abstract}

In a previous study, ${ }^{1}$ differences in solubilities in water among two geometrical isomers (mer- and fac-isomers) and two optical isomers $(\Lambda$ - and $\Delta$-isomers) of tris(amino acidato)cobalt(III) ([Co(aa) $\left.\left.)_{3}\right]\right)$ were examined. In a series of studies on the dissolution behavior of $\left[\mathrm{Co}(\mathrm{aa})_{3}\right]$, the $\Lambda$ - and $\Delta$-isomers have been expressed as the (+)- and (-)-isomers, respectively. The symbols $(+)$ and $(-)$ represent the dextrorotatory and levorotatory at $589 \mathrm{~nm}$, respectively. For most $\left[\mathrm{Co}(\mathrm{aa})_{3}\right]$, the merisomers were more soluble than the $f a c$-isomers, and for each geometrical isomer the (-)-isomer was more soluble than the $(+)$-isomer. However, in the case of tris(L-threoninato)cobalt(III) $\left(\left[\mathrm{Co}(\mathrm{L}-\mathrm{thr})_{3}\right]\right)$, the solubility of the $\mathrm{fac}-(+)$-isomer was larger than that of the mer-(+)-isomer. The reversed dissolution behavior, that the $f a c$-isomer is more soluble than the $m e r$-isomer, has also been qualitatively found for $\operatorname{tris}(\beta$-alaninato $)$ coblt(III) $\left(\left[\mathrm{Co}(\beta \text {-ala })_{3}\right]\right) .^{2}$ Unfortunately, the solubility of fac-(-)-[Co(L-thr $\left.)_{3}\right]$ could not be determined because of its insufficient yield. In this study, in order to confirm the abovementioned reversed dissolution behavior, the syntheses and separations of $f a c-(-)-\left[\mathrm{Co}(\mathrm{L}-\mathrm{thr})_{3}\right]$ and $f a c-\left[\mathrm{Co}(\beta \text {-ala })_{3}\right]$ were repeated until sufficient yields for the solubility determinations were effected.

It has been reported that the introduction of hydroxy groups into side chains of amino acids brings about an increase in the enthalpy $\left(\Delta_{\text {dis }} H^{\circ}\right)$ and entropy of dissolution $\left(\Delta_{\text {dis }} S^{\circ}\right)$ in water for $\left[\mathrm{Co}(\mathrm{aa})_{3}\right]$, presumably because of an inhibitory effect of the hydroxy group on the hydrophobic hydration of the parent $\left[\mathrm{Co}(\mathrm{aa})_{3}\right] .{ }^{1}$ In practice, the hydrophobic character of mer$(+)$-tris(L-serinato)cobalt(III) (mer- $\left.(+)-\left[\mathrm{Co}(\mathrm{L}-\mathrm{ser})_{3}\right]\right)$ was estimated to be lower than that of mer- $(+)$-tris(L-alaninato)cobalt(III) (mer- $\left.(+)-\left[\mathrm{Co}(\mathrm{L}-\mathrm{ala})_{3}\right]\right)$ based on the hydrophobic interaction of mer- $(+)-\left[\mathrm{Co}(\mathrm{aa})_{3}\right]$ with the tetrabutylammonium ion $\left(\mathrm{Bu}_{4} \mathrm{~N}^{+}\right){ }^{3}$ In order to estimate the hydrophobic character of
$\left[\mathrm{Co}(\mathrm{L}-\mathrm{thr})_{3}\right]$ and $\left[\mathrm{Co}(\beta \text {-ala })_{3}\right]$, the solubilities of mer-(+)$\left[\mathrm{Co}(\mathrm{L}-\mathrm{thr})_{3}\right]$ and mer- $\left[\mathrm{Co}(\beta \text {-ala })_{3}\right]$ in aqueous $\mathrm{Bu}_{4} \mathrm{NBr}$ solutions were also determined.

An examination of the dissolution behavior in solvents other than water is effective for distinguishing an effect characteristic of water, such as hydrophobic hydration. While the solubilities of $\left[\mathrm{Co}(\mathrm{aa})_{3}\right]$ in organic solvents have been little determined because of extremely low solubility, procedures for the separation of some optical isomers of $\left[\mathrm{Co}(\mathrm{aa})_{3}\right]$ are based upon the solubility differences of these isomers in ethanol. ${ }^{4}$ Thus, the solubility determinations for the mer-isomers of various $\left[\mathrm{Co}(\mathrm{aa})_{3}\right]$ and for the $f a c$-isomers of some $\left[\mathrm{Co}(\mathrm{aa})_{3}\right]$ in ethanol were attempted over the temperature range of 5 to $50{ }^{\circ} \mathrm{C}$. From these data, $\Delta_{\text {dis }} H^{\circ}$ and $\Delta_{\text {dis }} S^{\circ}$ of these chelates in ethanol were estimated. A comparison of $\Delta_{\text {dis }} H^{\circ}$ and $T \Delta_{\text {dis }} S^{\circ}$ in ethanol with those in water may be expected to provide information for distinguishing the interaction of these chelates with the solvent molecules.

\section{Experimental}

Procedures for the syntheses and separations of the stereoisomers of $\left[\mathrm{Co}(\mathrm{aa})_{3}\right]$ have been reported by previous studies. ${ }^{1,3}$ The solubility measurement was also carried out in the same manner as previously reported. ${ }^{1,3}$ In the solubility measurement, the temperature in a thermostat was maintained within $0.05{ }^{\circ} \mathrm{C}$ at the desired temperature. Commercial ethanol (reagent grade, Wako Chemical Industries Ltd.) was dried by refluxing overnight over calcium hydride, and was then distilled.

\section{Results}

The solubilities in $\mathrm{mol} \mathrm{kg}^{-1}\left(m_{0}\right)$ of $\mathrm{fac}-(-)-\left[\mathrm{Co}(\mathrm{L}-\mathrm{thr})_{3}\right]$ and $f a c-\left[\operatorname{Co}(\beta \text {-ala })_{3}\right]$ in water are listed in Table 1 . The solubility measurement was repeated at least four times at each 
Table 1. Solubilities $\left(m_{0}\right)$ of $f a c-(-)-\left[\mathrm{Co}(\mathrm{L}-\mathrm{thr})_{3}\right]$ and $\mathrm{fac}-$ $\left[\mathrm{Co}(\beta \text {-ala })_{3}\right]$ in Water ${ }^{\mathrm{a})}$

\begin{tabular}{|c|c|c|}
\hline \multirow[t]{2}{*}{$\theta /{ }^{\circ} \mathrm{C}$} & fac-(-)-[Co(L-thr $\left.)_{3}\right]$ & $f a c-\left[\operatorname{Co}(\beta \text {-ala })_{3}\right]$ \\
\hline & $m_{0} / 10^{-1} \mathrm{~mol} \mathrm{~kg}^{-1}$ & $m_{0} / \mathrm{mol} \mathrm{kg}^{-1}$ \\
\hline 5 & $6.8(0.1)$ & \\
\hline 10 & $6.57(0.04)$ & $5.8(0.2)$ \\
\hline 15 & $6.29(0.06)$ & $5.83(0.08)$ \\
\hline 20 & $6.19(0.03)$ & $5.71(0.09)$ \\
\hline 25 & $6.05(0.09)$ & $5.29(0.05)$ \\
\hline 30 & $5.51(0.09)$ & $5.0(0.2)$ \\
\hline 35 & $5.4(0.1)$ & $4.8(0.1)$ \\
\hline 40 & $5.36(0.09)$ & $4.7(0.1)$ \\
\hline 45 & $5.31(0.05)$ & $4.7(0.1)$ \\
\hline 50 & $5.5(0.2)$ & $4.9(0.2)$ \\
\hline
\end{tabular}

a) Errors defined as $95 \%$ confidence levels are given in parentheses. temperature. The $m_{0}$ values are the mean of the respective experimental values and the errors are represented by $95 \%$ confidence limits. The errors for $f a c-(-)-\left[\mathrm{Co}(\mathrm{L}-\mathrm{thr})_{3}\right]$ were within $2 \%$ of the mean values, except for the measurement at elevated temperatures, but those for $f a c$ - $\left[\mathrm{Co}(\beta \text {-ala })_{3}\right]$ were within $4 \%$.

In Table 2, the values for $m_{0}$ of $f a c-(-)$ - and mer- $(-)-[\mathrm{Co}(\mathrm{L}-$ thr $\left.)_{3}\right]$, fac- and mer-[Co( $\beta$-ala $\left.)_{3}\right]$, mer- $(-)-\left[\mathrm{Co}(\mathrm{L}-\mathrm{ala})_{3}\right]$, mer$(-+)$ - and mer-(+-)-tris(DL-2-aminobutyrato)cobalt(III) (mer- $(-+)$ - and mer-(+-)-[Co(DL-aba $\left.\left.)_{3}\right]\right)$, fac-(-)-, mer(+)-, and mer-(-)-tris(L-valinato)cobalt(III) ( fac-(-)-, mer$(+)-$, and mer-(-)-[Co(L-val $\left.\left.)_{3}\right]\right)$, mer- $(-+)$ - and mer- $(+-)-$ tris(DL-norvalinato)cobalt(III) (mer- $(-+)$ - and mer- $(+-)$ [Co(DL-nval) $\left.\left.)_{3}\right]\right)$, fac-(-)- and mer-(-)-tris(L-prolinato)cobal$\mathrm{t}(\mathrm{III})$ (fac-(-)- and mer-(-)-[Co(L-pro $\left.)_{3}\right]$ ), and mer-(+)tris(L-leucinato)cobalt(III) (mer- $\left.(+)-\left[\mathrm{Co}(\mathrm{L}-\mathrm{leu})_{3}\right]\right)$ in ethanol are tabulated. The abbreviations of $(-+)-\left[\mathrm{Co}(\mathrm{DL}-\mathrm{aa})_{3}\right]$ and $(+-)-\left[\mathrm{Co}(\mathrm{DL}-\mathrm{aa})_{3}\right]$ stand for the mixtures of $(-)-\left[\mathrm{Co}(\mathrm{D}-\mathrm{aa})_{3}\right]$

Table 2. Solubilities $\left(m_{0}\right)$ of $m e r-(-)-\left[\mathrm{Co}(\mathrm{L}-\mathrm{ala})_{3}\right]$, fac- and $m e r-\left[\mathrm{Co}(\beta \text {-ala })_{3}\right]$, fac- $(-)-$ and $m e r-(-)-\left[\mathrm{Co}(\mathrm{L}-\mathrm{thr})_{3}\right]$, $m e r-(-+)-$ and $m e r-$ $(+-)-\left[\mathrm{Co}(\mathrm{DL}-\mathrm{aba})_{3}\right]$, fac-(-)-, mer-(+)-, and mer-(-)-[Co(L-val $\left.)_{3}\right]$, mer-(-+)- and mer-(+-)-[Co(DL-nval) $\left.)_{3}\right]$, fac- $(-)-$ and $m e r-(-)-$ $\left[\mathrm{Co}(\mathrm{L}-\mathrm{pro})_{3}\right]$, and $m e r-(+)-\left[\mathrm{Co}(\mathrm{L}-\mathrm{leu})_{3}\right]$ in Ethanol ${ }^{\mathrm{a})}$

\begin{tabular}{|c|c|c|c|c|c|c|c|c|}
\hline$\theta /{ }^{\circ} \mathrm{C}$ & $\frac{f a c-\left[\operatorname{Co}(\beta \text {-ala })_{3}\right]}{m_{0} / 10^{-4} \mathrm{~mol} \mathrm{~kg}^{-1}}$ & $\frac{f a c-(-)-\left[\mathrm{Co}(\mathrm{L}-\mathrm{thr})_{3}\right]}{m_{0} / 10^{-4} \mathrm{~mol} \mathrm{~kg}^{-1}}$ & \multicolumn{2}{|c|}{$\frac{f a c-(-)-\left[\mathrm{Co}(\mathrm{L}-\mathrm{val})_{3}\right]}{m_{0} / 10^{-4} \mathrm{~mol} \mathrm{~kg}^{-1}}$} & \multicolumn{2}{|c|}{$\frac{f a c-(-)-\left[\mathrm{Co}(\mathrm{L}-\mathrm{pro})_{3}\right]}{m_{0} / 10^{-5} \mathrm{~mol} \mathrm{~kg}^{-1}}$} & $\frac{m e r-(-)-\left[\mathrm{Co}(\mathrm{L}-\mathrm{ala})_{3}\right]}{m_{0} / 10^{-4} \mathrm{~mol} \mathrm{~kg}^{-1}}$ & $\frac{m e r-\left[\operatorname{Co}(\beta \text {-ala })_{3}\right]}{m_{0} / 10^{-5} \mathrm{~mol} \mathrm{~kg}^{-1}}$ \\
\hline 5 & & $2.5(0.1)$ & \multicolumn{2}{|c|}{$3.53(0.06)$} & \multicolumn{2}{|l|}{$6.5(0.2)$} & & \\
\hline 10 & $10.2(0.5)$ & $2.61(0.05)$ & \multicolumn{2}{|c|}{$3.21(0.03)$} & \multicolumn{2}{|l|}{$7.1(0.2)$} & & \\
\hline 15 & $9.5(0.5)$ & $2.29(0.03)$ & \multicolumn{2}{|c|}{$3.01(0.05)$} & \multicolumn{2}{|l|}{$8.1(0.2)$} & & $7.8(0.3)$ \\
\hline 20 & $9.8(0.5)$ & $2.39(0.03)$ & \multicolumn{2}{|c|}{$2.83(0.06)$} & \multicolumn{2}{|l|}{$8.7(0.2)$} & $4.63(0.05)$ & $7.2(0.3)$ \\
\hline 25 & $8.0(0.5)$ & $2.38(0.05)$ & \multicolumn{2}{|c|}{$2.68(0.03)$} & \multicolumn{2}{|l|}{$10.3(0.2)$} & $4.9(0.1)$ & $7.4(0.4)$ \\
\hline 30 & $7.9(0.2)$ & $2.43(0.05)$ & 2.54 & $0.05)$ & $12.2(0.3)$ & & $5.36(0.04)$ & $7.6(0.4)$ \\
\hline 35 & $7.7(0.3)$ & $2.40(0.07)$ & 2.44 & $0.05)$ & $13.7(0.3)$ & & $5.3(0.1)$ & $6.9(0.9)$ \\
\hline 40 & $9.5(0.2)$ & $2.51(0.03)$ & 2.34 & $0.02)$ & $15.5(0.2)$ & & $5.5(0.1)$ & $7.2(0.5)$ \\
\hline 45 & & & 2.24 & $0.03)$ & $18.3(0.2)$ & & $6.1(0.1)$ & $6.2(0.5)$ \\
\hline 50 & & & 2.18 & $0.03)$ & & & $6.5(0.1)$ & $6.6(0.3)$ \\
\hline$\theta /{ }^{\circ} \mathrm{C}$ & $m e r-(-)-\left[\mathrm{Co}(\mathrm{L}-\mathrm{thr})_{3}\right]$ & mer- $(-+)-[\mathrm{Co}$ & $\left.(\text { DL-aba })_{3}\right]$ & mer- $(+-)$ & $-\left[\mathrm{Co}(\mathrm{DL}-\mathrm{aba})_{3}\right]$ & mer & $-(+)-\left[\mathrm{Co}(\mathrm{L}-\mathrm{val})_{3}\right]$ & ner-(-)-[Co(L-val $\left.)_{3}\right]$ \\
\hline & $m_{0} / 10^{-2} \mathrm{~mol} \mathrm{~kg}^{-1}$ & $m_{0} / 10^{-3} \mathrm{mc}$ & $\mathrm{ol} \mathrm{kg}^{-1}$ & $m_{0} / 10$ & )$^{-3} \mathrm{~mol} \mathrm{~kg}^{-1}$ & & $/ 10^{-2} \mathrm{~mol} \mathrm{~kg}^{-1}$ & $m_{0} / 10^{-1} \mathrm{~mol} \mathrm{~kg}^{-1}$ \\
\hline 5 & $0.82(0.01)$ & $3.99(0$. & .06) & & & & $7.5(0.1)$ & $5.5(0.1)$ \\
\hline 10 & $0.892(0.007)$ & $4.15(0$. & $.07)$ & & & & $8.3(0.2)$ & $5.26(0.01)$ \\
\hline 15 & $1.02(0.01)$ & $4.67(0$. & $.06)$ & & $6(0.1)$ & & $9.1(0.1)$ & $5.26(0.09)$ \\
\hline 20 & $1.18(0.01)$ & $5.1(0.1$ & & & $73(0.05)$ & & $9.7(0.1)$ & $5.5(0.1)$ \\
\hline 25 & $1.32(0.02)$ & $5.68(0$. & .04) & & $93(0.07)$ & & $11.0(0.3)$ & $5.5(0.1)$ \\
\hline 30 & $1.54(0.01)$ & $6.49(0$. & $.08)$ & & $17(0.03)$ & & $12.1(0.2)$ & $5.7(0.1)$ \\
\hline 35 & $1.81(0.02)$ & $7.4(0.1$ & & & $50(0.05)$ & & $14.4(0.2)$ & \\
\hline 40 & $2.15(0.02)$ & $8.5(0.1$ & & & $89(0.03)$ & & $16.1(0.1)$ & \\
\hline 45 & $2.66(0.07)$ & $9.81(0$. & .09) & & $23(0.02)$ & & $18.0(0.7)$ & \\
\hline 50 & $3.24(0.08)$ & $11.0(0.3$ & & & $7(0.2)$ & & & \\
\hline$\theta /{ }^{\circ} \mathrm{C}$ & $m e r-(-+)-[\mathrm{Co}(\mathrm{L}$ & $\left.(\text { DL-nval })_{3}\right]$ & mer $-(+-)$ & [Co(DL-nva & mer- & $(-)-[$ & $\left.\mathrm{Co}(\mathrm{L}-\mathrm{pro})_{3}\right]$ & $\operatorname{er}-(+)-\left[\mathrm{Co}(\mathrm{L}-\mathrm{leu})_{3}\right]$ \\
\hline & $m_{0} / 10^{-2} \mathrm{mo}$ & $10 \mathrm{~kg}^{-1}$ & $m_{0} / 10$ & ${ }^{-1} \mathrm{~mol} \mathrm{~kg}^{-1}$ & $m_{0}$ & $/ 10^{-2}$ & $\mathrm{~mol} \mathrm{~kg}^{-1}$ & $m_{0} / 10^{-1} \mathrm{~mol} \mathrm{~kg}^{-1}$ \\
\hline 5 & $3.52(0.0$ & .06) & & $3(0.01)$ & & 1.50 & $(0.01)$ & $1.32(0.02)$ \\
\hline 10 & $3.47(0.0$ & $.04)$ & & $1(0.01)$ & & 1.52 & $(0.02)$ & $1.31(0.01)$ \\
\hline 15 & $3.55(0.0$ & $.08)$ & & $1(0.01)$ & & 1.51 & $(0.04)$ & $1.31(0.01)$ \\
\hline 20 & $3.57(0.0$ & $.04)$ & & $9(0.01)$ & & 1.46 & $(0.02)$ & $1.31(0.01)$ \\
\hline 25 & $3.62(0.0$ & $06)$ & & $2(0.01)$ & & 1.51 & $(0.03)$ & $1.32(0.02)$ \\
\hline 30 & $3.72(0.0$ & 08) & & $4(0.01)$ & & 1.54 & $(0.04)$ & $1.45(0.02)$ \\
\hline 35 & $3.88(0.0$ & 05) & & $2(0.01)$ & & 1.58 & $(0.05)$ & $1.48(0.02)$ \\
\hline 40 & $4.08(0.0$ & 07) & & $5(0.04)$ & & 1.65 & $(0.04)$ & $1.52(0.03)$ \\
\hline 45 & $4.34(0.0$ & .05) & & $3(0.03)$ & & 1.73 & $(0.04)$ & $1.57(0.01)$ \\
\hline 50 & $4.66(0.0$ & .04) & & $5(0.04)$ & & 1.86 & $(0.03)$ & $1.57(0.01)$ \\
\hline
\end{tabular}

a) Errors defined as $95 \%$ confidence levels are given in parentheses. 
and $(+)-\left[\mathrm{Co}(\mathrm{L}-\mathrm{aa})_{3}\right]$, and of $(+)-\left[\mathrm{Co}(\mathrm{D}-\mathrm{aa})_{3}\right]$ and $(-)-[\mathrm{Co}(\mathrm{L}-$ aa) $\left.{ }_{3}\right]$, respectively. In the procedure used for the solubility determination, the saturated solution was passed through a glasswool layer to remove the solid phase. In the cases of $f a c$ - and $\operatorname{mer}-\left[\mathrm{Co}(\beta \text {-ala })_{3}\right]$, it was found that quite a small amount of solid phases of the respective chelates contaminated into the saturated solutions. The large errors in these solubility determinations may be attributed to unavoidable contamination. In other cases, the errors were substantially within $3 \%$.

In Table 3, the solubility values in $\mathrm{mol} \mathrm{kg}^{-1}$ in aqueous $\mathrm{Bu}_{4} \mathrm{NBr}$ solutions $(m)$ for mer- $(+)-\left[\mathrm{Co}(\mathrm{L}-\mathrm{thr})_{3}\right]$, mer- $[\mathrm{Co}(\beta$ ala $\left.)_{3}\right]$, and $\mathrm{fac}_{-}(-)-\left[\mathrm{Co}(\mathrm{L}-\text { pro })_{3}\right]$ are listed. In these determinations, the errors were less than $2 \%$, with some exceptions.

The values for $\ln m_{0}$ or $\ln m$ were plotted against $1 / T$. Typical plots are depicted in Fig. 1, where the solubility curves of fac-(-) $-\left[\mathrm{Co}(\mathrm{L}-\mathrm{thr})_{3}\right]$ and $f a c-\left[\mathrm{Co}(\beta \text {-ala })_{3}\right]$ in water, and of mer- $(+)-\left[\mathrm{Co}(\mathrm{L}-\mathrm{leu})_{3}\right], \quad$ mer- $(-+)-\left[\mathrm{Co}(\mathrm{DL}-\mathrm{nval})_{3}\right]$, and $\mathrm{fac}$ $(-)-\left[\mathrm{Co}(\mathrm{L}-\mathrm{Val})_{3}\right]$ in ethanol are drawn. The standard free energy $\left(\Delta_{\text {dis }} G^{\circ}\right)$, enthalpy $\left(\Delta_{\text {dis }} H^{\circ}\right)$, and entropy of dissolution $\left(\Delta_{\text {dis }} S^{\circ}\right)$ at $25{ }^{\circ} \mathrm{C}$ were estimated by applying a least-squares analysis to the above temperature dependences of the solubilities. The method for estimating these thermodynamic functions, which has been closely described in previous work, ${ }^{5}$ is equivalent to fitting the solubility data to

$$
R \ln m\left(\text { or } m_{0}\right)=\mathrm{A}+\mathrm{B} / T+\mathrm{C} \ln T+\mathrm{D} T+\mathrm{E} T^{2}+\ldots,
$$

where $R$ is the gas constant and $\mathrm{A}, \mathrm{B}, \mathrm{C}, \mathrm{D}$, and $\mathrm{E} \ldots$ are constants.

The standard state for the chelate in the solution is 1 mol kg-1. For the chelates which have considerably large solu-

Table 3. Solubilities $(m)$ of $m e r-(+)-\left[\mathrm{Co}(\mathrm{L}-\mathrm{thr})_{3}\right]$, mer- $\left[\mathrm{Co}(\beta \text {-ala })_{3}\right]$, and $f a c-(-)-\left[\mathrm{Co}(\mathrm{L}-\text { pro })_{3}\right]$ in $\mathrm{Aqueous} \mathrm{Bu}_{4} \mathrm{NBr}$ Solutions ${ }^{\text {a) }}$

\begin{tabular}{|c|c|c|c|c|}
\hline \multirow[t]{3}{*}{$\theta /{ }^{\circ} \mathrm{C}$} & \multicolumn{4}{|c|}{$\mathrm{Bu}_{4} \mathrm{NBr}$ concentration $m_{\mathrm{s}} / \mathrm{mol} \mathrm{kg}^{-1}$} \\
\hline & 0.159 & 0.600 & 1.420 & 1.983 \\
\hline & \multicolumn{4}{|c|}{$m / 10^{-3} \mathrm{~mol} \mathrm{~kg}^{-1}$ for $m e r-(+)-\left[\mathrm{Co}(\mathrm{L}-\mathrm{thr})_{3}\right]$} \\
\hline 10 & $1.05(0.02)$ & $0.867(0.004)$ & $0.92(0.02)$ & $0.99(0.02)$ \\
\hline 15 & $1.07(0.01)$ & $1.06(0.01)$ & $0.94(0.01)$ & $1.00(0.03)$ \\
\hline 20 & $1.18(0.01)$ & $1.08(0.03)$ & $0.99(0.03)$ & $1.00(0.03)$ \\
\hline 25 & $1.21(0.02)$ & $1.37(0.01)$ & $0.994(0.001)$ & $1.02(0.02)$ \\
\hline 30 & $1.26(0.02)$ & $1.47(0.01)$ & $1.06(0.01)$ & $1.07(0.02)$ \\
\hline 35 & $1.35(0.01)$ & $1.48(0.02)$ & $1.15(0.02)$ & $1.13(0.03)$ \\
\hline 40 & $1.47(0.04)$ & $1.53(0.03)$ & $1.23(0.02)$ & $1.24(0.03)$ \\
\hline 45 & & $1.66(0.02)$ & & \\
\hline \multirow[t]{3}{*}{$\theta /{ }^{\circ} \mathrm{C}$} & \multicolumn{4}{|c|}{$\mathrm{Bu}_{4} \mathrm{NBr}$ concentration $m_{\mathrm{s}} / \mathrm{mol} \mathrm{kg}^{-1}$} \\
\hline & 0.136 & 0.593 & 0.969 & 1.704 \\
\hline & \multicolumn{4}{|c|}{$m / 10^{-1} \mathrm{~mol} \mathrm{~kg}^{-1}$ for $m e r-\left[\operatorname{Co}(\beta \text {-ala })_{3}\right]$} \\
\hline 10 & $1.72(0.01)$ & $1.81(0.01)$ & $1.71(0.02)$ & $1.32(0.01)$ \\
\hline 15 & $1.97(0.01)$ & $2.03(0.03)$ & $1.94(0.01)$ & $1.49(0.02)$ \\
\hline 20 & $2.28(0.01)$ & $2.32(0.02)$ & $2.20(0.01)$ & $1.68(0.04)$ \\
\hline 25 & $2.60(0.02)$ & $2.64(0.02)$ & $2.48(0.02)$ & $1.89(0.02)$ \\
\hline 30 & $3.04(0.03)$ & $2.97(0.04)$ & $2.77(0.02)$ & $2.08(0.01)$ \\
\hline 35 & $3.55(0.04)$ & $3.36(0.02)$ & $3.10(0.02)$ & $2.22(0.05)$ \\
\hline 40 & $4.09(0.02)$ & $3.82(0.04)$ & $3.47(0.01)$ & $2.24(0.05)$ \\
\hline 45 & $4.69(0.03)$ & $4.34(0.02)$ & $3.84(0.05)$ & \\
\hline 50 & $5.5(0.1)$ & $4.84(0.04)$ & $4.19(0.07)$ & \\
\hline \multirow[t]{3}{*}{$\theta /{ }^{\circ} \mathrm{C}$} & \multicolumn{4}{|c|}{$\mathrm{Bu}_{4} \mathrm{NBr}$ concentration $m_{\mathrm{s}} / \mathrm{mol} \mathrm{kg}^{-1}$} \\
\hline & 0.205 & 0.571 & 0.966 & 1.332 \\
\hline & \multicolumn{4}{|c|}{$m / 10^{-3} \mathrm{~mol} \mathrm{~kg}^{-1}$ for fac $(-)-\left[\mathrm{Co}(\mathrm{L}-\text { pro })_{3}\right]$} \\
\hline 5 & $7.41(0.05)$ & $8.91(0.08)$ & & \\
\hline 10 & $7.44(0.03)$ & $8.92(0.04)$ & $9.04(0.08)$ & \\
\hline 15 & $7.49(0.06)$ & $9.03(0.05)$ & $9.29(0.05)$ & $8.89(0.09)$ \\
\hline 20 & $7.67(0.05)$ & $9.24(0.07)$ & $9.55(0.09)$ & $9.25(0.07)$ \\
\hline 25 & $7.90(0.06)$ & $9.56(0.08)$ & $9.97(0.08)$ & $9.67(0.06)$ \\
\hline 30 & $8.18(0.06)$ & $10.0(0.1)$ & $10.5(0.1)$ & $10.2(0.1)$ \\
\hline 35 & $8.62(0.04)$ & $10.7(0.2)$ & $11.3(0.1)$ & $10.8(0.1)$ \\
\hline 40 & $9.24(0.06)$ & $11.5(0.1)$ & $11.9(0.1)$ & $11.5(0.1)$ \\
\hline 45 & $9.89(0.06)$ & $12.6(0.1)$ & $12.9(0.1)$ & $12.3(0.1)$ \\
\hline 50 & $10.6(0.1)$ & $13.8(0.1)$ & $13.9(0.1)$ & $13.3(0.1)$ \\
\hline 55 & & & $15.0(0.1)$ & $14.7(0.1)$ \\
\hline 60 & & & & $16.1(0.2)$ \\
\hline
\end{tabular}

a) Errors defined as $95 \%$ confidence levels are given in parentheses. 
bilities such as $f a c-\left[\mathrm{Co}(\beta \text {-ala })_{3}\right]$ and $m e r-(-)-\left[\mathrm{Co}(\mathrm{L}-\text { pro })_{3}\right]$ in water, an activity correction is required to estimate the standard thermodynamic functions from the temperature dependences of the solubilities. However, these saturated solutions are tentatively regarded as being ideal dilute solutions because of the lack of a data requirement for an activity correction.

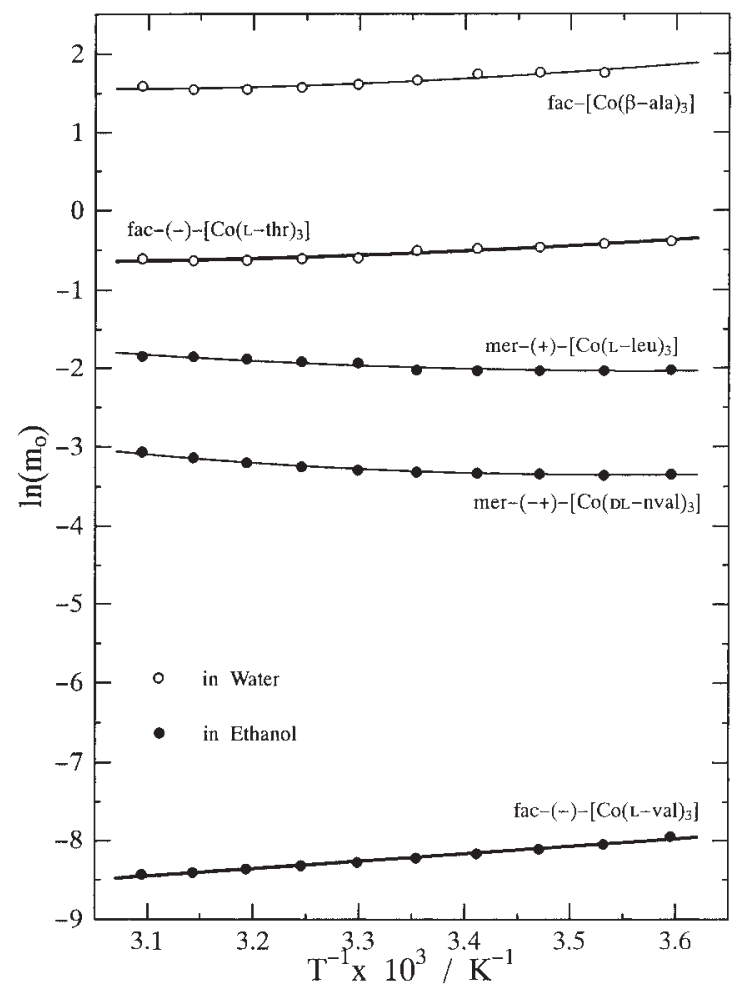

Fig. 1. Solubility curves of $f a c-\left[\operatorname{Co}(\beta \text {-ala })_{3}\right]$ and $f a c-(-)-$ $\left[\mathrm{Co}(\mathrm{L}-\mathrm{thr})_{3}\right]$ in water, and of mer- $(+)-\left[\mathrm{Co}(\mathrm{L}-\mathrm{leu})_{3}\right]$, mer$(-+)-\left[\mathrm{Co}(\mathrm{DL}-\mathrm{nval})_{3}\right]$, and $\mathrm{fac}-(-)-\left[\mathrm{Co}(\mathrm{L}-\mathrm{Val})_{3}\right]$ in ethanol illustrated by plotting $\ln m_{0}$ against $1 / T$.
The thus-obtained values for $\Delta_{\text {dis }} G^{\circ}, \Delta_{\text {dis }} H^{\circ}$, and $T \Delta_{\text {dis }} S^{\circ}$ in water and in ethanol at $25{ }^{\circ} \mathrm{C}$ are tabulated in Table 4 . The errors of $\Delta_{\text {dis }} G^{\circ}$ and $\Delta_{\text {dis }} H^{\circ}$, estimated from the standard deviations of the least-squares analysis, are also given in parentheses.

\section{Discussion}

Estimation of the Hydrophobic Character of mer-(+)$\left[\mathrm{Co}(\mathrm{L}-\mathrm{thr})_{3}\right]$, mer- $\left[\mathrm{Co}(\beta \text {-ala })_{3}\right]$, and $f a c-(-)-\left[\mathrm{Co}(\mathrm{L}-\mathrm{pro})_{3}\right]$. In order to clarify the effect of $\mathrm{Bu}_{4} \mathrm{NBr}$ on the solubilities of mer- $(+)-\left[\mathrm{Co}(\mathrm{L}-\mathrm{thr})_{3}\right]$, mer- $\left[\mathrm{Co}(\beta \text {-ala })_{3}\right]$, and fac- $(-)-[\mathrm{Co}(\mathrm{L}-$ pro $\left.)_{3}\right]$, the values of $\log \left(m_{0} / m\right)$ for these chelates at $25{ }^{\circ} \mathrm{C}$ were plotted against the $\mathrm{Bu}_{4} \mathrm{NBr}$ concentration $\left(m_{\mathrm{s}}\right)$ in Fig. 2 . The effect of $\mathrm{Bu}_{4} \mathrm{NBr}$ on $m e r-(-)-\left[\mathrm{Co}(\mathrm{L}-\text { pro })_{3}\right]$ was not examined because of a quite large solubility in water. Similar plots for various mer- $(+)-\left[\mathrm{Co}(\mathrm{L}-\mathrm{aa})_{3}\right]$ have shown that the solubilities of hydrophobic chelates, such as mer- $(+)-\left[\mathrm{Co}(\mathrm{L}-\mathrm{val})_{3}\right]$ and mer- $(+)-\left[\mathrm{Co}(\mathrm{L}-\mathrm{leu})_{3}\right]$, increase upon the addition of $\mathrm{Bu}_{4} \mathrm{NBr}$ (salting-in effect), though the solubilities of hydrophilic chelates, such as mer-[Co(gly $\left.)_{3}\right]$ and $\operatorname{mer}-(+)-\left[\mathrm{Co}(\mathrm{L}-\mathrm{Ser})_{3}\right]$, decrease (salting-out effect). ${ }^{3}$

While the curves in Fig. 2 are merely drawn to manifest the effect of $\mathrm{Bu}_{4} \mathrm{NBr}$, the effect of $\mathrm{Bu}_{4} \mathrm{NBr}$ on the solubility of mer- $(+)-\left[\mathrm{Co}(\mathrm{L}-\mathrm{thr})_{3}\right]$ cannot be expressed by a smooth curve. A similar solubility variation by the addition of $\mathrm{Bu}_{4} \mathrm{NBr}$ has also been observed for mer-(+)-[Co(L-ser $\left.)_{3}\right]{ }^{3}$ The effect of $\mathrm{Bu}_{4} \mathrm{NBr}$ on the solubility of $m e r$ - $\left[\mathrm{Co}(\beta \text {-ala })_{3}\right]$, that is, the salting-in effect in the low- $m_{\mathrm{s}}$ region and the salting-out effect in the high- $m_{\mathrm{s}}$ region, is similar to the effects on mer- $\left[\mathrm{Co}(\mathrm{gly})_{3}\right]$ and $\operatorname{mer}-(+)-\left[\mathrm{Co}(\mathrm{L}-\mathrm{ala})_{3}\right] .{ }^{3}$ On the other hand, the addition of $\mathrm{Bu}_{4} \mathrm{NBr}$ brings about a salting-in effect on $f a c-(-)-\left[\mathrm{Co}\left(\mathrm{L}_{-}\right.\right.$ pro) $)_{3}$.

The effect of $\mathrm{Bu}_{4} \mathrm{NBr}$ on the solubilities of various mer$\left[\mathrm{Co}(\mathrm{aa})_{3}\right]$ can be interpreted from the standpoint of a hydrophobic interaction between mer-[Co(aa) $\left.)_{3}\right]$ and the $\mathrm{Bu}_{4} \mathrm{~N}^{+}$ ion. ${ }^{3}$ The hydrophobic interaction is caused by an increase in

Table 4. Free Energy $\left(\Delta_{\text {dis }} G^{\circ}\right)$, Enthalpy $\left(\Delta_{\text {dis }} H^{\circ}\right)$, and Entropy of Dissolution $\left(\Delta_{\text {dis }} S^{\circ}\right)$ for Various $\left[\mathrm{Co}(\text { aa })_{3}\right]$ in Water and in Ethanol at $25^{\circ} \mathrm{C}^{\mathrm{a}}$ )

\begin{tabular}{|c|c|c|c|c|c|c|}
\hline \multirow[t]{2}{*}{ Chelates } & \multicolumn{3}{|c|}{ In water } & \multicolumn{3}{|c|}{ In ethanol } \\
\hline & $\Delta_{\mathrm{dis}} G^{\circ}$ & $\Delta_{\mathrm{dis}} H^{\circ}$ & $T \Delta_{\text {dis }} S^{\circ}$ & $\Delta_{\mathrm{dis}} G^{\circ}$ & $\Delta_{\mathrm{dis}} H^{\circ}$ & $T \Delta_{\text {dis }} S^{\circ}$ \\
\hline$f a c-\left[\operatorname{Co}(\beta \text {-ala })_{3}\right]$ & $-4.16(0.02)$ & $-8.5(0.3)$ & -4.3 & $17.5(0.1)$ & $-9(2)$ & -26 \\
\hline fac- $(-)-\left[\mathrm{Co}(\mathrm{L}-\mathrm{thr})_{3}\right]$ & $1.32(0.03)$ & $-6.4(0.6)$ & -7.7 & $20.69(0.08)$ & $0.5(0.9)$ & -20.2 \\
\hline$f a c-(-)-\left[\mathrm{Co}(\mathrm{L}-\text { pro })_{3}\right]$ & $12.89(0.01)^{\mathrm{b})}$ & $5.7(0.1)^{b)}$ & $-7.2^{\mathrm{b})}$ & $22.76(0.05)$ & $19.5(0.4)$ & -3.3 \\
\hline$f a c-(-)-\left[\mathrm{Co}(\mathrm{L}-\mathrm{val})_{3}\right]$ & $12.93(0.02)^{\mathrm{b})}$ & $\left.-5.0(0.4)^{b}\right)$ & $-17.9^{b)}$ & $20.39(0.01)$ & $-8.0(0.1)$ & -28.4 \\
\hline $\operatorname{mer}-(-)-\left[\mathrm{Co}(\mathrm{L}-\mathrm{ala})_{3}\right]$ & $0.95(0.02)^{\mathrm{b})}$ & $1.1(0.2)^{\mathrm{b})}$ & $0.1^{\mathrm{b})}$ & $18.89(0.07)$ & $8.2(0.8)$ & -10.7 \\
\hline$m e r-\left[\operatorname{Co}(\beta \text {-ala })_{3}\right]$ & $3.33(0.02)^{b)}$ & $20.8(0.2)^{\mathrm{b})}$ & $17.5^{\mathrm{b})}$ & $23.5(0.1)$ & $-1.7(0.4)$ & -25.2 \\
\hline$m e r-(-)-\left[\mathrm{Co}(\mathrm{L}-\mathrm{thr})_{3}\right]$ & $7.31(0.01)^{\mathrm{b})}$ & $16.4(0.1)^{\mathrm{b})}$ & $9.1^{b)}$ & $10.72(0.03)$ & $21.9(0.2)$ & 11.2 \\
\hline$m e r-(-+)-\left[\mathrm{Co}(\mathrm{DL}-\mathrm{aba})_{3}\right]$ & $10.37(0.02)^{\mathrm{c})}$ & $\left.22.1(0.1)^{\mathrm{c}}\right)$ & $11.7^{\mathrm{c})}$ & $12.80(0.02)$ & $18.5(0.4)$ & 5.7 \\
\hline$m e r-(+-)-\left[\mathrm{Co}(\mathrm{DL}-\mathrm{aba})_{3}\right]$ & $4.63(0.04)^{\mathrm{c})}$ & $6.4(0.3)^{\mathrm{c})}$ & $1.8^{\mathrm{c})}$ & $13.74(0.01)$ & $8.8(0.2)$ & -4.9 \\
\hline$m e r-(-)-\left[\mathrm{Co}(\mathrm{L}-\text { pro })_{3}\right]$ & $-0.3(0.4)^{\mathrm{b})}$ & $48(5)^{b)}$ & $48^{\mathrm{b})}$ & $10.41(0.03)$ & $2.7(0.2)$ & -7.7 \\
\hline $\operatorname{mer}-(+)-\left[\mathrm{Co}(\mathrm{L}-\mathrm{val})_{3}\right]$ & $5.78(0.02)^{\mathrm{c})}$ & $-13.7(0.3)^{\mathrm{c})}$ & $-19.5^{\mathrm{c})}$ & $5.47(0.04)$ & $16.5(0.3)$ & 11.0 \\
\hline$m e r-(-)-\left[\mathrm{Co}(\mathrm{L}-\mathrm{val})_{3}\right]$ & $2.96(0.02)^{\mathfrak{c})}$ & $0.4(0.2)^{\mathrm{c})}$ & $-2.6^{\mathrm{c})}$ & $1.48(0.06)$ & $5(2)$ & 4 \\
\hline $\operatorname{mer}-(-+)-\left[\mathrm{Co}(\mathrm{DL}-\mathrm{nval})_{3}\right]$ & $10.12(0.03)^{\mathrm{c})}$ & $\left.-5.2(0.5)^{\mathrm{c}}\right)$ & $-15.3^{\mathrm{c})}$ & $8.23(0.01)$ & $4.1(0.1)$ & -4.1 \\
\hline $\operatorname{mer}-(+-)-\left[\mathrm{Co}(\mathrm{DL}-\mathrm{nval})_{3}\right]$ & $9.56(0.02)^{b)}$ & $1.6(0.4)^{b)}$ & $-8.0^{\mathrm{b})}$ & $5.22(0.04)$ & $4.9(0.2)$ & -0.3 \\
\hline$m e r-(+)-\left[\mathrm{Co}(\mathrm{L}-\mathrm{leu})_{3}\right]$ & $19.68(0.02)^{\mathrm{c})}$ & $\left.-2.6(0.1)^{\mathrm{c}}\right)$ & $-22.3^{\mathrm{c})}$ & $4.94(0.03)$ & $5.4(0.6)$ & 0.5 \\
\hline
\end{tabular}

a) Units of $\Delta_{\text {dis }} G^{\circ}, \Delta_{\text {dis }} H^{\circ}$, and $T \Delta_{\text {dis }} S^{\circ}$ are $\mathrm{kJ} \mathrm{mol}^{-1}$. Errors for $\Delta_{\text {dis }} G^{\circ}$ and $\Delta_{\text {dis }} H^{\circ}$ estimated from the standard deviations of the least-squares analysis are given in parentheses. b) Taken from Ref. 1. c) Taken from Ref. 3. 


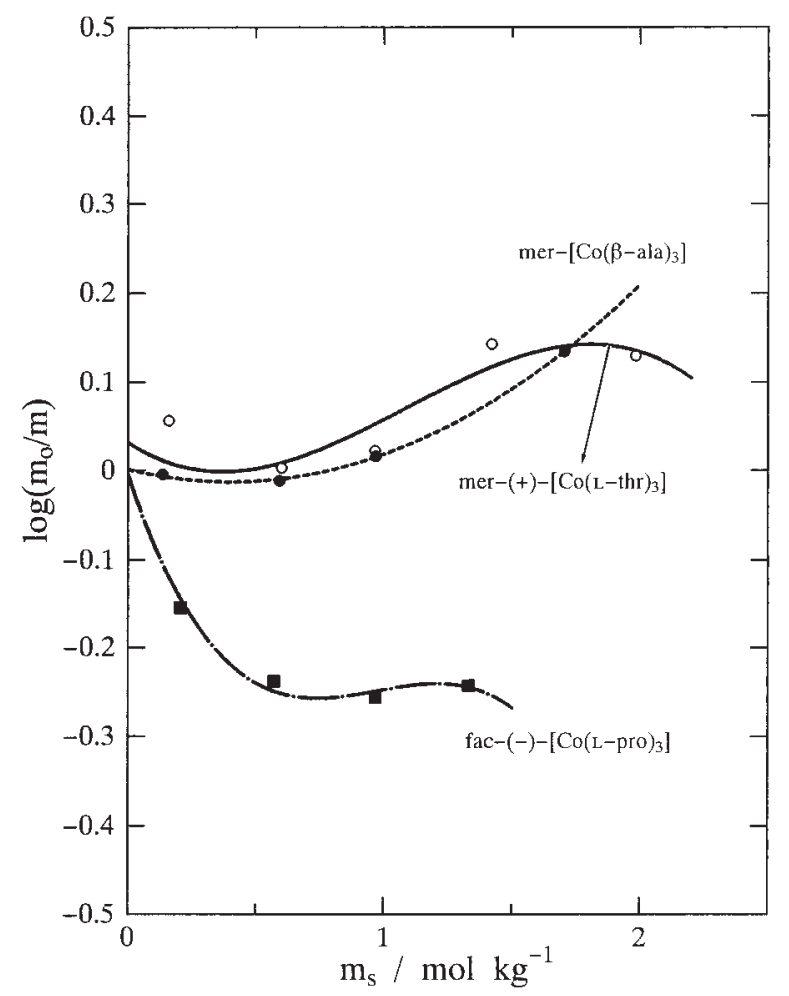

Fig. 2. Effect of $\mathrm{Bu}_{4} \mathrm{NBr}$ on mer-[Co( $\beta$-ala $\left.)_{3}\right]$, mer- $(+)$ $\left[\mathrm{Co}(\mathrm{L}-\mathrm{thr})_{3}\right]$, and $\mathrm{fac}-(-)-\left[\mathrm{Co}(\mathrm{L}-\mathrm{pro})_{3}\right]$ depicted by plotting $\log \left(m_{0} / m\right)$ against $m_{\mathrm{s}}$. The curves are tentatively drawn in order to manifest the effect of $\mathrm{Bu}_{4} \mathrm{NBr}$.

both the enthalpy and the entropy due to overlapping of hydrophobic hydration shells around both the mer-[Co(aa) $\left.)_{3}\right]$ and $\mathrm{Bu}_{4} \mathrm{~N}^{+}$ions. In order to examine the effect of $\mathrm{Bu}_{4} \mathrm{NBr}$ on mer- $\left[\mathrm{Co}(\beta \text {-ala })_{3}\right]$, mer- $(+)-\left[\mathrm{Co}(\mathrm{L}-\mathrm{thr})_{3}\right]$, and $\mathrm{fac}-(-)-[\mathrm{Co}(\mathrm{L}-$ pro $\left.)_{3}\right]$, the free energy $\left(\Delta_{\text {tr }} G^{\circ}\right)$, enthalpy $\left(\Delta_{\text {tr }} H^{\circ}\right)$, and entropy of transfer $\left(\Delta_{\text {tr }} S^{\circ}\right)$ from water to aqueous $\mathrm{Bu}_{4} \mathrm{NBr}$ solutions at $25{ }^{\circ} \mathrm{C}$ for these chelates were calculated by

$$
\Delta_{\text {tr }} Y^{\circ}=\Delta_{\text {dis }} Y^{\circ}\left(\mathrm{Bu}_{4} \mathrm{NBr}\right)-\Delta_{\text {dis }} Y^{\circ}(\text { water }),
$$

where $Y$ denotes free energy or enthalpy or entropy, and $Y\left(\mathrm{Bu}_{4} \mathrm{NBr}\right)$ and $Y$ (water) refer to the values of $Y$ in aqueous $\mathrm{Bu}_{4} \mathrm{NBr}$ solution and in water, respectively.

For mer- $\left[\mathrm{Co}(\beta \text {-ala })_{3}\right]$, mer- $(+)-\left[\mathrm{Co}(\mathrm{L}-\mathrm{thr})_{3}\right]$, and $\mathrm{fac}-(-)$ [Co(L-pro $\left.)_{3}\right], \Delta_{\text {tr }} H^{\circ}$ are plotted against $T \Delta_{\text {tr }} S^{\circ}$ in Fig. 3. The correlation found is given by

$$
\Delta_{\mathrm{tr}} H^{\circ}=0.96 \times T \Delta_{\mathrm{tr}} S^{\circ} \quad(\gamma=0.998),
$$

where $\gamma$ is the correlation coefficient.

The excellent fit to Eq. 3 explains the relatively small effect of $\mathrm{Bu}_{4} \mathrm{NBr}$ on the solubilities shown in Fig. 2. The finding that the single correlation of Eq. 3 holds regardless of the concentration of $\mathrm{Bu}_{4} \mathrm{NBr}$ and the kind of $\left[\mathrm{Co}(\mathrm{aa})_{3}\right]$ suggests that the values of $\Delta_{\mathrm{tr}} H^{\circ}$ and $T \Delta_{\mathrm{tr}} S^{\circ}$ for the transfer process from water to $\mathrm{Bu}_{4} \mathrm{NBr}$ solution with a common concentration may be used as a measure for the hydrophobic character of $\left[\mathrm{Co}(\mathrm{aa})_{3}\right] .^{3}$

In Fig. 4, for the transfer process of every chelate so far examined from water to a $0.97 \mathrm{~mol} \mathrm{~kg}^{-1} \mathrm{Bu}_{4} \mathrm{NBr}$ solution, $\Delta_{\text {tr }} H^{\circ}$ is plotted against $T \Delta_{\text {tr }} S^{\circ}$. This plot gives an excellent correlation, indicated by

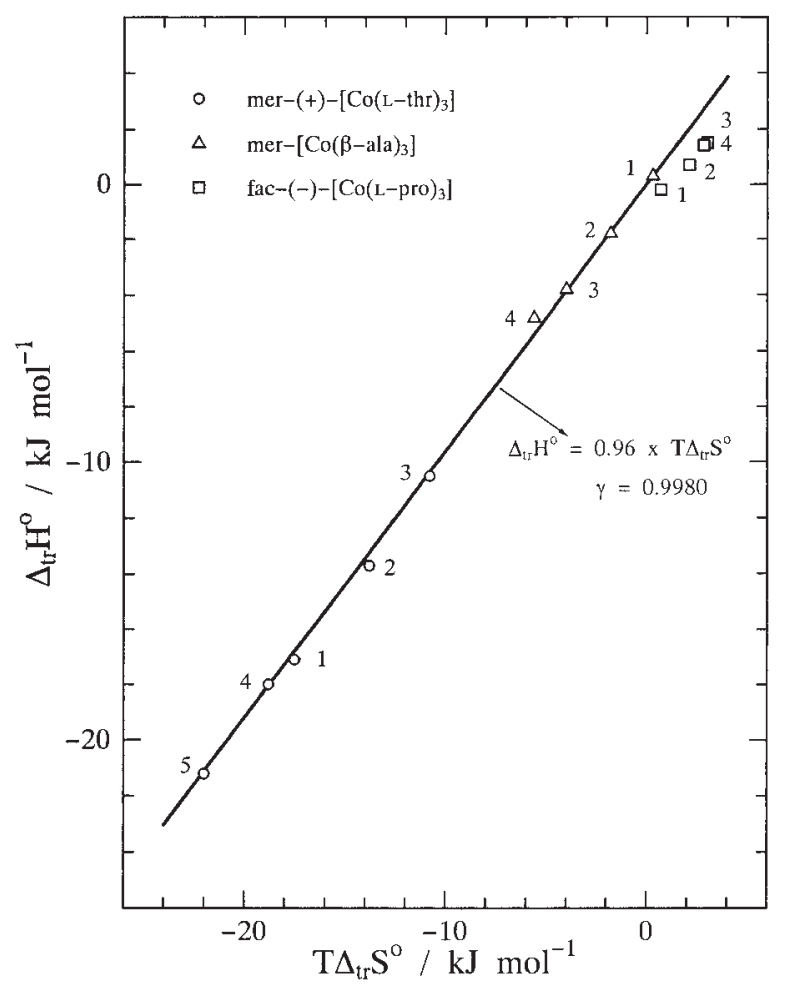

Fig. 3. Correlation between $\Delta_{\mathrm{tr}} H^{\circ}$ and $T \Delta_{\mathrm{tr}} S^{\circ}$ for the transfer process of mer- $\left[\mathrm{Co}(\beta \text {-ala })_{3}\right]$, mer- $(+)-\left[\mathrm{Co}(\mathrm{L}-\mathrm{thr})_{3}\right]$, and fac-(-)-[Co(L-pro $\left.)_{3}\right]$ from water to aqueous $\mathrm{Bu}_{4} \mathrm{NBr}$ solutions. The number given beside each mark represents increasing sequence of $\mathrm{Bu}_{4} \mathrm{NBr}$ concentration $m_{\mathrm{s}}$.

$$
\Delta_{\mathrm{tr}} H^{\circ}=0.90 \times T \Delta_{\mathrm{tr}} S^{\circ} \quad(\gamma=0.997) .
$$

In the correlation of Eq. 4, the data for some $\mathrm{fac}$-[Co(aa) $\left.)_{3}\right]$ in addition to the data for various $m e r-\left[\mathrm{Co}(\mathrm{aa})_{3}\right]$ are included.

The positive $\Delta_{\mathrm{tr}} H^{\circ}$ and $T \Delta_{\mathrm{tr}} S^{\circ}$ values can be attributed to a hydrophobic interaction between $\left[\mathrm{Co}(\mathrm{aa})_{3}\right]$ and the $\mathrm{Bu}_{4} \mathrm{~N}^{+}$ion. Therefore, it may be concluded that $\left[\mathrm{Co}(\mathrm{aa})_{3}\right]$, which gives a larger positive value for $\Delta_{\mathrm{tr}} H^{\circ}$ or $T \Delta_{\mathrm{tr}} S^{\circ}$, has a larger hydrophobic character. On the other hand, the negative values for $\Delta_{\mathrm{tr}} H^{\circ}$ and $T \Delta_{\mathrm{tr}} S^{\circ}$ imply a rather hydrophilic interaction of $\left[\mathrm{Co}(\mathrm{aa})_{3}\right]$ with its surroundings.

Figure 4 shows that $\operatorname{mer}-(+)-\left[\mathrm{Co}(\mathrm{L}-\mathrm{thr})_{3}\right], \operatorname{mer}-\left[\mathrm{Co}(\beta \text {-ala })_{3}\right]$, and $\mathrm{fac}_{-}(-)-\left[\mathrm{Co}(\mathrm{L}-\mathrm{pro})_{3}\right]$ have a rather hydrophilic character. This result for $f a c-(-)-\left[\mathrm{Co}(\mathrm{L}-\text { pro })_{3}\right]$ suggests that the hydrophobic character of the aliphatic ring in the side chain of L-proline is very small. Hecht et al. ${ }^{6}$ have also reported by using infrared spectroscopy that the hydrophobic character of some amino acids increases in the order of glycine $<$ methionine $<$ proline $\sim$ alanine $<$ valine $\sim$ leucine.

Dissolution Behavior of $\left[\mathrm{Co}(\mathrm{aa})_{3}\right]$ in Water and in Ethanol. A correlation between the solubilities of various $\left[\mathrm{Co}(\mathrm{aa})_{3}\right]$ in water and those in ethanol is depicted in Fig. 5 by plotting $\Delta_{\text {dis }} G^{\circ}$ in ethanol $\left(\Delta_{\text {dis }} G^{\circ}\right.$ (ethanol)) against $\Delta_{\text {dis }} G^{\circ}$ in water $\left(\Delta_{\text {dis }} G^{\circ}\right.$ (water)). Because an activity correction was not applied to the solubility data for $f a c-\left[\operatorname{Co}(\beta \text {-ala })_{3}\right]$ and $m e r-(-)-\left[\mathrm{Co}(\mathrm{L}-\text { pro })_{3}\right]$ in water, the $\Delta_{\mathrm{dis}} G^{\circ}$ data for these chelates should be regarded as rough approximations. This plot shows that the chelates examined in the present investigation 


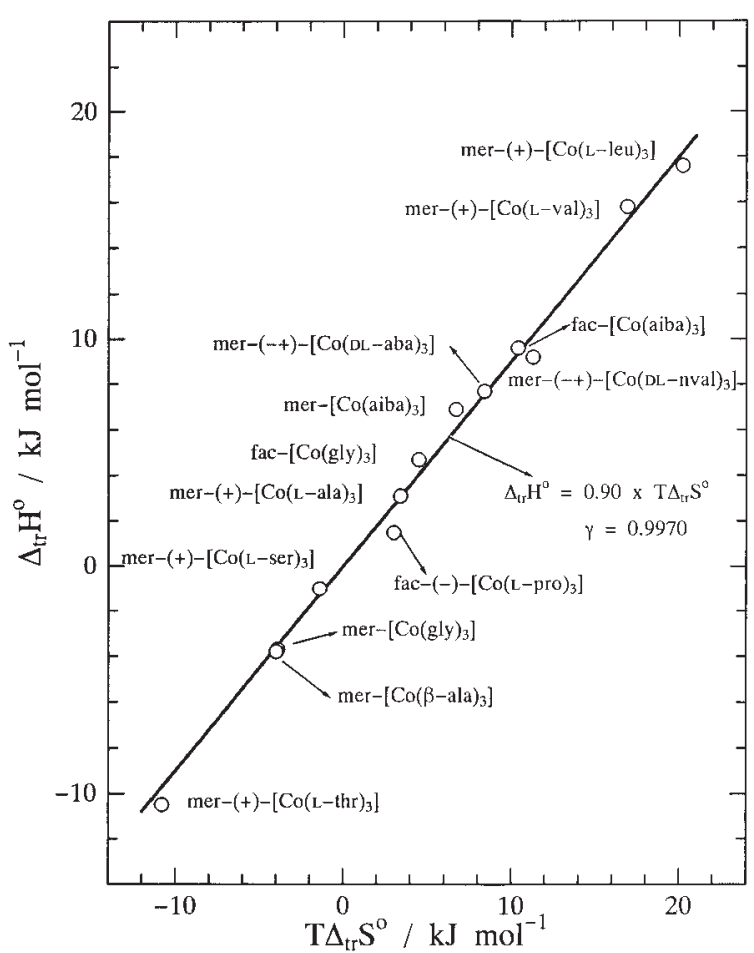

Fig. 4. Compensation relation between $\Delta_{\mathrm{tr}} H^{\circ}$ and $T \Delta_{\mathrm{tr}} S^{\circ}$ for the transfer process of various $\left[\mathrm{Co}(\mathrm{aa})_{3}\right]$ from water to $0.97 \mathrm{~mol} \mathrm{~kg}^{-1}$ aqueous $\mathrm{Bu}_{4} \mathrm{NBr}$ solution.

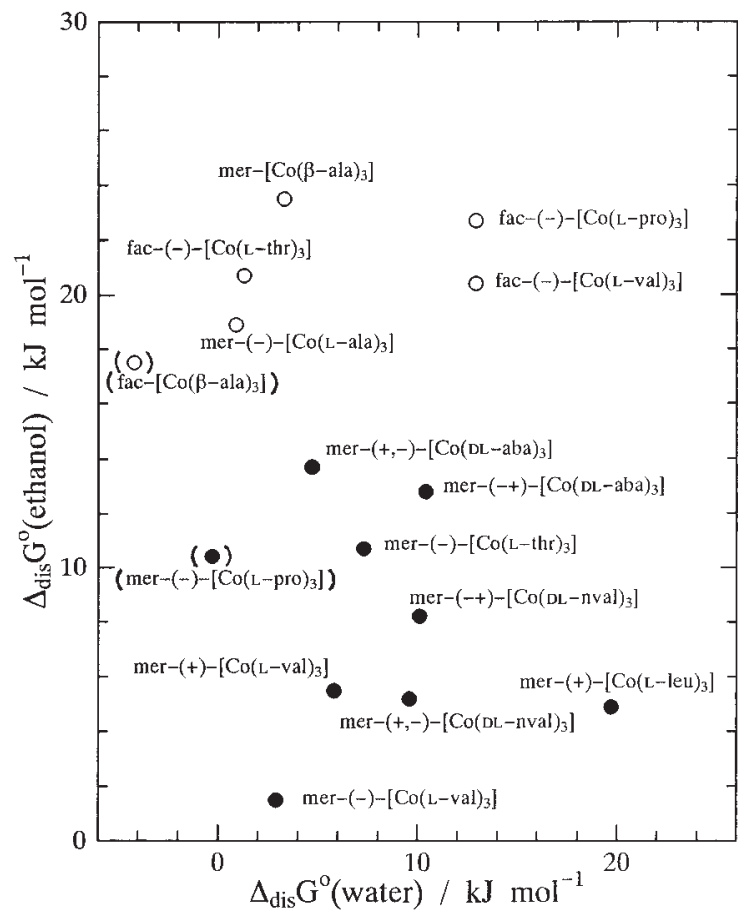

Fig. 5. Free energy relation between dissolution in water and dissolution in ethanol for various $\left[\mathrm{Co}(\mathrm{aa})_{3}\right]$. Open symbols stand for the group composed of principally hydrophilic chelates and full symbols represent the group composed of essentially hydrophobic chelates. The data for $f a c-\left[\operatorname{Co}(\beta \text {-ala })_{3}\right]$ and $m e r-(-)-\left[\operatorname{Co}(\mathrm{L}-\text { pro })_{3}\right]$ in parentheses are regarded as rough approximations (see text).

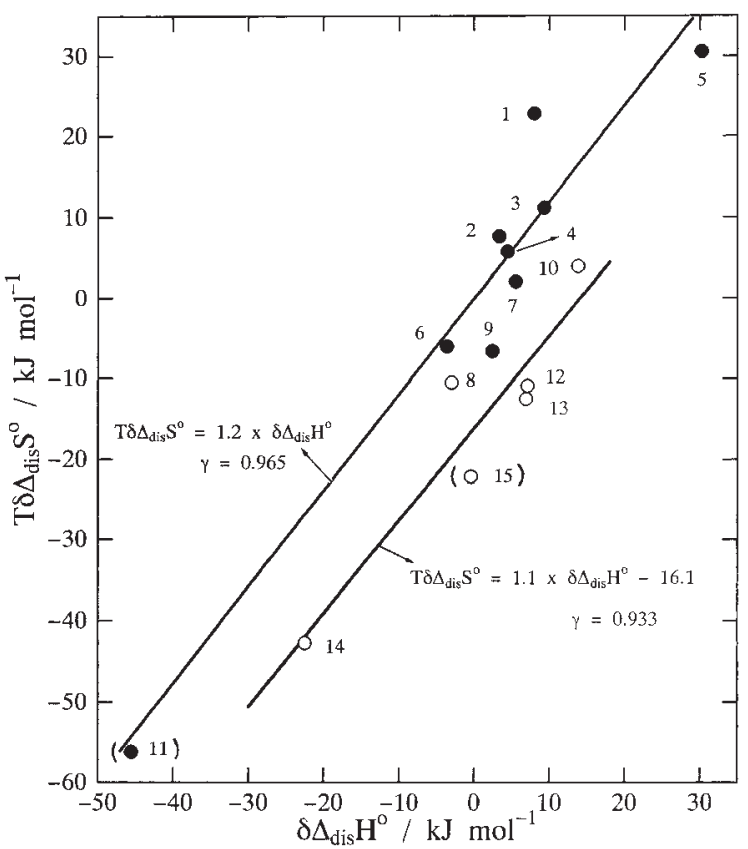

Fig. 6. Correlation between $T \delta \Delta_{\text {dis }} S^{\circ}$ and $\delta \Delta_{\text {dis }} H^{\circ}$ for the hypothetical transfer process of various $\left[\mathrm{Co}(\mathrm{aa})_{3}\right]$ from water to ethanol. The open and full symbols have the same significances as Fig. 5. The number given beside each symbol represents increasing sequence of $\delta \Delta_{\text {dis }} G^{\circ}$ and corresponds to the chelate as follows: $1, \operatorname{mer}-(+)-[\mathrm{Co}(\mathrm{L}-$ leu $\left.)_{3}\right] ; 2$, mer-(+-)-[Co(DL-nval) $\left.)_{3}\right] ; 3$, mer- $(-+)-[\mathrm{Co}-$ (DL-nval $\left.)_{3}\right] ; 4$, mer- $(-)-\left[\mathrm{Co}(\mathrm{L}-\mathrm{val})_{3}\right] ; 5$, mer- $(+)-[\mathrm{Co}(\mathrm{L}-$ val $\left.)_{3}\right] ; 6$, mer-(-+)-[Co(DL-aba) $\left.)_{3}\right] ; 7$, mer- $(-)-[\mathrm{Co}(\mathrm{L}-$ thr $\left.)_{3}\right] ; \quad 8, \quad f a c-(-)-\left[\mathrm{Co}(\mathrm{L}-\mathrm{val})_{3}\right] ; \quad 9, \quad$ mer- $(+-)-[\mathrm{Co}(\mathrm{DL}-$ $\left.\mathrm{aba})_{3}\right] ; \quad 10$, fac-(-)-[Co(L-pro $\left.)_{3}\right] ; 11, \operatorname{mer}-(-)-[\mathrm{Co}(\mathrm{L}-$ pro $\left.)_{3}\right] ; 12$, mer-(-)-[Co(L-ala $\left.)_{3}\right] ; 13$, fac $^{-}(-)-\left[\mathrm{Co}(\mathrm{L}-\mathrm{thr})_{3}\right]$; 14 , mer- $\left[\operatorname{Co}(\beta \text {-ala })_{3}\right] ; 15$, fac- $\left[\operatorname{Co}(\beta \text {-ala })_{3}\right]$. The data for mer-(-)-[Co(L-pro $\left.)_{3}\right]$ and $f a c-\left[\mathrm{Co}(\beta \text {-ala })_{3}\right]$ in parentheses are excluded from strict discussion (see text).

may be roughly divided into two groups. One group consists of rather hydrophilic chelates, such as $\left[\mathrm{Co}(\mathrm{L}-\mathrm{thr})_{3}\right]$ and $[\mathrm{Co}(\beta$ ala $)_{3}$. Within this group, the solubilities in water are considerably larger than those in ethanol, and the solubilities in ethanol decrease with the decreasing solubilities in water. Another group is composed of essentially hydrophobic chelates, such as $\left[\mathrm{Co}(\mathrm{DL}-\mathrm{nval})_{3}\right],\left[\mathrm{Co}(\mathrm{L}-\mathrm{val})_{3}\right]$, and $\left[\mathrm{Co}(\mathrm{L}-\mathrm{leu})_{3}\right]$. The solubilities of these chelates in ethanol are larger than those in water, and the solubilities in ethanol increase with the decreasing solubilities in water.

For mer-(-)-[Co(L-ser $\left.)_{3}\right]$, mer- $\left[\mathrm{Co}(\mathrm{gly})_{3}\right]$, and $\mathrm{fac}_{-}(-)$$\left[\mathrm{Co}(\mathrm{L}-\mathrm{ala})_{3}\right]$, the solubility measurement in ethanol was attempted, but could not be accomplished by the present spectrophotometric procedure because of extremely low solubilities. However, the solubilities of these chelates in ethanol can be estimated to be smaller than the solubility of $\operatorname{mer}-\left[\operatorname{Co}(\beta \text {-ala })_{3}\right]$ in ethanol. The $\Delta_{\text {dis }} G^{\circ}$ (water) values for these chelates are 4.2, 8.6 , and $7.5 \mathrm{~kJ} \mathrm{~mol}^{-1}$, respectively. ${ }^{1}$ From both of the abovementioned estimations for the solubilities in ethanol and the $\Delta_{\text {dis }} G^{\circ}$ (water) values, the experimental points for mer-(-)$\left[\mathrm{Co}(\mathrm{L}-\mathrm{ser})_{3}\right], \quad m e r-\left[\mathrm{Co}(\mathrm{gly})_{3}\right]$, and $\mathrm{fac}-(-)-\left[\mathrm{Co}(\mathrm{L}-\mathrm{ala})_{3}\right]$ in Fig. 5 may be expected to be classified into the former group. 
In order to examine the difference between $\Delta_{\text {dis }} G^{\circ}$ (water) and $\Delta_{\text {dis }} G^{\circ}$ (ethanol), the differences between $\Delta_{\text {dis }} G^{\circ}, \Delta_{\text {dis }} H^{\circ}$, and $\Delta_{\text {dis }} S^{\circ}$ in ethanol and those in water at $25^{\circ} \mathrm{C}$ were calculated by

$$
\delta \Delta_{\text {dis }} Y^{\circ}=\Delta_{\text {dis }} Y^{\circ}(\text { ethanol })-\Delta_{\text {dis }} Y^{\circ}(\text { water }),
$$

where $\Delta_{\text {dis }} Y$ (ethanol) and $\Delta_{\text {dis }} Y$ (water) refer to the values of $\Delta_{\text {dis }} Y$ in ethanol and in water, respectively.

In Fig. 6, the values for $T \delta \Delta_{\text {dis }} S^{\circ}$ are plotted against $\delta \Delta_{\text {dis }} H^{\circ}$. The data for mer-(-)-[Co(L-pro $\left.)_{3}\right]$ and $f a c-[\operatorname{Co}(\beta$ ala $)_{3}$ ], which correspond to No. 11 and 15 , respectively, were also excluded from any following discussion for the abovementioned reason. The chelates numbered from 1 to 5 have negative $\delta \Delta_{\text {dis }} G^{\circ}$; that is, the solubilities of these chelates in ethanol are larger than the solubilities in water. The $\delta \Delta_{\text {dis }} G^{\circ}$ values for the other chelates are positive; that is, the solubilities in ethanol are smaller than those in water. The numbers given beside the symbols correspond to the respective $\left[\mathrm{Co}(\mathrm{aa})_{3}\right]$ cited in the caption of Fig. 6, and also stand for increasing sequence of the $\delta \Delta_{\text {dis }} G^{\circ}$ values.

Based on the discussion concerning the results shown in Fig. 5, the chelates in Fig. 6 are divided into two groups: relatively hydrophilic $\left[\mathrm{Co}(\mathrm{aa})_{3}\right]$ (open symbols) and rather hydrophobic $\left[\mathrm{Co}(\mathrm{aa})_{3}\right]$ (full symbols). The correlation between $T \delta \Delta_{\text {dis }} S^{\circ}$ and $\delta \Delta_{\text {dis }} H^{\circ}$ within each group is satisfactory. Despite the above classification for $\left[\mathrm{Co}(\mathrm{aa})_{3}\right]$, the values for $\delta \Delta_{\text {dis }} H^{\circ}$ are almost positive, except for $\operatorname{mer}$ - $\left[\mathrm{Co}(\beta \text {-ala })_{3}\right]$, that is, $\Delta_{\text {dis }} H^{\circ}$ (ethanol) $\geq \Delta_{\text {dis }} H^{\circ}$ (water) for most [Co(aa) $)_{3}$. In the former group (open symbols), the $T \delta \Delta_{\text {dis }} S^{\circ}$ values are roughly negative: $T \Delta_{\text {dis }} S^{\circ}$ (ethanol) $\leq T \Delta_{\text {dis }} S^{\circ}$ (water), and both smaller $\Delta_{\text {dis }} H^{\circ}$ (water) and larger $T \Delta_{\text {dis }} S^{\circ}$ (water) bring about a larger solubility in water. In the latter group (full symbols), the
$T \delta \Delta_{\text {dis }} S^{\circ}$ values are nearly positive: $T \Delta_{\text {dis }} S^{\circ}($ ethanol) $\geq$ $T \Delta_{\text {dis }} S^{\circ}$ (water). In spite of a larger $\Delta_{\text {dis }} H^{\circ}$ (ethanol), a larger $T \Delta_{\text {dis }} S^{\circ}$ (ethanol) results in a larger solubility in ethanol. This finding seems to be consistent with the classification that the latter group is comprised of hydrophobic [Co(aa) 3 ; that is, $\Delta_{\text {dis }} H^{\circ}$ (water) and $T \Delta_{\text {dis }} S^{\circ}$ (water) are smaller than $\Delta_{\text {dis }} H^{\circ}$ (ethanol) and $T \Delta_{\text {dis }} S^{\circ}$ (ethanol) owing to hydrophobic hydration of the latter $\left[\mathrm{Co}(\mathrm{aa})_{3}\right]$.

For (-)-[Co(L-val $\left.)_{3}\right]$ and (-)-[Co(L-pro $\left.)_{3}\right]$, the solubilities of $m e r$-isomers are larger than those of $f a c$-isomers in both ethanol and water (see Fig. 5). These findings are presumably applicable to every $\left[\mathrm{Co}(\mathrm{aa})_{3}\right]$ so-far examined, except for $\left[\mathrm{Co}(\mathrm{L}-\mathrm{thr})_{3}\right]$ and $\left[\mathrm{Co}(\beta \text {-ala })_{3}\right]$. On the contrary, the solubility of $m e r-\left[\operatorname{Co}(\beta \text {-ala })_{3}\right]$ is less than that of $f a c-\left[\operatorname{Co}(\beta \text {-ala })_{3}\right]$ in both ethanol and water. In the case of $(-)-\left[\mathrm{Co}(\mathrm{L}-\mathrm{thr})_{3}\right]$, the solubility of the mer-isomer in ethanol is larger than that of the $f a c$-isomer, but the solubility of the mer-isomer in water is smaller than that of the $f a c$-isomer. These findings seem to indicate that the difference in the solubility between the mer-and $f a c$-isomers of $\left[\mathrm{Co}(\mathrm{aa})_{3}\right]$ is not produced by a difference in the lattice forces in the solid phases of the respective isomers.

\section{References}

1 Y. Yoshimura, Bull. Chem. Soc. Jpn., 75, 741 (2002).

2 M. B. Celap, S. R. Nikeyic, T. J. Janjic, and V. N. Nikolic, Inorg. Chem., 6, 2063 (1967).

3 Y. Yoshimura, Bull. Chem. Soc. Jpn., 72, 1285 (1999).

4 R. D. Gillard and N. C. Payne, J. Chem. Soc. A, 1969, 1197.

5 Y. Yoshimura, Can. J. Chem., 67, 2108 (1989).

6 D. Hecht, L. Tadesse, and L. Walters, J. Am. Chem. Soc., 115, 3336 (1993). 